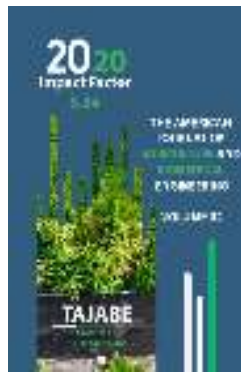

\title{
Harmful Cicada Families Tettigometridae Of The Fergana Valley
}

\author{
Alevtina Grigorevna Kojevnikova \\ Doctor Of Biological Science, Professor, Department Of "Plant Protection", Tashkent State \\ Agrarian University, Uzbekistan
}

Journal Website:

http://usajournalshub.c

om/index,php/tajabe

Copyright: Original content from this work may be used under the terms of the creative commons attributes 4.0 licence.

\section{ABSTRACT}

The article presents materials on the study of cicadas Psammotettix striatus (L.) and Psammotettix dubovskyi Vilb. in Fergana Valley, their morphological and biological abilities, systematic position, distribution, harmfulness, food connections and peculiarities their diagnosis.

\section{KEYWORDS}

Cicadas, species, composition, family, genus, species, diagnosis, Psammotettix striatus (L.), Psammotettix dubovskyi Vilb.

\section{INTRODUCTION}

At present, simultaneously with cotton growing, the Republic is successfully developing the production of grain crops and legumes, rice, corn, as well as vegetables, melons, potatoes, fruits, grapes, etc. for the environment by methods of combating harmful organisms.

In the Fergana Valley of Uzbekistan, due attention is paid to this issue.
The study of cicadas is of great importance, since many species are pests of agricultural crops, some species carry viral plant diseases [1].

Cicadas belong to the order Homoptera. To suck out juices from plants, they have a piercing-sucking mouth apparatus.

These insects are distinguished by a wide variety in species composition and in the 
number of individual species. Some of them can multiply in large quantities [2].

Cicadids belong to the arthropod type Arthropoda, the insect class - Insecta, the Homoptera detachment - Homoptera, and the series - Auchenorrhyncha [3].

This group of insects is very ancient in origin and flourishing in the modern era [2].

Cycadids suck out juices from plants, inflict wounds on vegetative parts with the ovipositor, and some species transmit viral diseases of various crops [4]. It is noted that weakened plants are sometimes susceptible to damage by various diseases $[5,6]$.

\section{RESEARCH OBJECT AND METHODS}

The material for this work was 10-year collection and research of cicadas in the conditions of the Fergana Valley. We used special and generally accepted techniques in entomology.

\section{THE MAIN FINDINGS AND RESULTS}

Cicadids of the genus Psammotettix Haupt, 1929, belongs to the Latreille family, 1825 . Some harmful species of cicadas of this genus that live in the Fergana Valley (Psammotettix striatus (L.) and Psammotettix dubovskyi Vilb.) Are usually not harmful on farms, but since they are in are currently potential pests of cereals and other crops, the identification and study of these pests is of practical importance.

Information about cicadids damaging cereals is available in the works of a number of authors $[4,7]$.

Our long-term and literary studies on the study of cicadas have shown that many of them are pests of cultivated plants.

This concerns the species Psammotettix striatus (L.) and Psammotettix dubovskyi Vilb., Which, with their piercing-sucking mouth apparatus, suck juices from plants, their negative effect on young plants is especially noticeable.

Cycadids of the genus Psammotettix Haupt, 1929 , are characterized by small or mediumsized species. They are usually colored brown and pale greenish. On their favorite cereal crops, they need to be recognized and identified.

The dimensions of the cicadas of this genus are on average $3.3-5.0 \mathrm{~mm}$. The body from above is more or less in an intense pattern. Closer to a pair of compound eyes, on the parietal margin, simple eyes lie. Not very long antennae are located in depressions under complex eyes.

Vertex pentagonal, flat or slightly curved, sharply protruding in front of compound eyes, separated by a well-pronounced medial stripe extending two-thirds of its length in front, posterior vertex smoothly curved, lateral edges slightly widened anteriorly. The transition to the face is rounded. The frontoclypeus is convex, tapering evenly downward, with a longitudinal light stripe and alternating dark and light transverse stripes diverging to the sides. Anticlypeus weakly convex, rounded apically, more than half as long as frontoclypeus. The bores are wide; more than two-thirds of their inner edges border on the anticlypeus. Pronotum arcuately curved anteriorly, also convex in shape, straight posteriorly, smoothly rounded to the sides. Scutellum small, triangular, with short transverse striation.

The wings are rather developed, transparent, longer than the abdomen, sometimes some cells of the forewings are dark-colored, the veins are light.

The pygophore has numerous macrosetae at the dorsal margin. The genital valva is long. The genital plates are short, with a non-straight outer margin. Styli with well-defined preapical angle and blunt apex. 
A characteristic feature of the genus is the structure of the aedeagus of its species, the trunk of which is spoon-shaped or grooved at the end.

The detailed writing of the genus given by Haupt in 1929 is valid to this day [7].

In the conditions of the Fergana Valley, we were interested in two species that preferentially feed on cereals, these are Psammotettix striatus (L.) and Psammotettix dubovskyi Vilb.

Psammotettix striatus (L.), as a species numerous on cereal crops, was first described by Linnaenus in 1758 [4]. In 1850, the researcher Dahlbot redescribes the species under the name Psammotettix alienus (Psammotettix alienus Dahl.). Then Ribaut redescribes the species in 1925 and gives it the name Psammotettix provincialis (Psammotettix provincialis Rib.). Then many researchers red escribe this species and, finally, come to a consensus that, given the existing morphological features and according to the structure of the male genital apparatus, the species Psammotettix striatus was described for the first time by Linnaenus. Thus, according to the rules of priority, the name Psammotettix striatus (L.) remains for the cicada.

As can be assumed, the above contradictions are associated with the fact that the species Psammotettix striatus (L.), depending on the habitat conditions, has a feature of changing the color intensity.

In the conditions of the Fergana Valley, Psammotettix striatus (L.) looks like this: The body of Psammotettix striatus (L.) is brownish, with an indistinct brown pattern, slender and beautiful. On the vertex there are usually two interrupted stripes and spots at the posterior margin. Pronotum with longitudinal stripes. The cells of the fore wings are bordered with brown color. Length of male 3.3-3.6 mm, female $3 \cdot 5-4.3 \mathrm{~mm}$.
Psammotettix striatus (L.), a very common species. Its range covers North Africa, temperate countries in Asia, in the CIS it is distributed everywhere, except for the far north.

According to G.K. Dubovsky in Central Asia, this is one of the most numerous species of cicadas, found everywhere on the plains, in the foothills and mountains [4].

In Kazakhstan, according to I.D. Mityaev [5], the species is numerous in deserts, semideserts, steppes, river floodplains, foothills of Tarbagatai and Tien Shan. The highest number is observed in the steppe zone of the southeast of Kazakhstan.

According to A.F. Emelyanov [8] Psammotettix striatus (L.) harms spike crops, especially as a vector of viral diseases: winter wheat mosaic, winter wheat white mosaic, wheat dwarfism. These diseases are widespread and affect many cereals.

In Kazakhstan, on sown areas, the cicada Psammotettix striatus (L.) is common on winter wheat, rye, spring wheat and corn. Adults are numerous in the crops of beets and strawberries [5].

According to our information, Psammotettix striatus (L.) harms rice, corn, wheat, barley, and oats, in addition to alfalfa, lobia, potatoes, beets, and carrots. This is a polyphagous species, in spring it harms young plants of winter wheat, causing their oppression.

Studies have shown that harm from Psammotettix striatus (L.) is mainly manifested in several ways. Cicadas suck the sap out of plants, causing the plants to wilt and may die. Usually cicadas, when laying eggs, apply ovipositor wounds on the vegetative parts of the plant.

Since many authors note $[4,5,8]$ that the species Psammotettix striatus (L.) is a carrier of viral diseases of cereal crops, therefore, 
healthy and weakened plants are at risk of being affected by various diseases, if any.

The species Psammotettix dubovskyi Vilb., 1960, named after the Uzbek entomologist G.K.Dubovsky by the Estonian researcher Yu.G. Vilbaste, occurs in large numbers, according to G.K.Dubovsky [4], in Fergana Valley in walnut forests, subalpine belt. It is noticeably less abundant on plains, where it prefers floodplains of rivers and sais and other humid and shaded places. The species is widespread throughout Central Asia.

Cicada is polyphagous, in the mountains it harms potatoes, alfalfa, beets, carrots, corn, wheat, oats, millet. On irrigated lands, rice, corn, alfalfa, beans, beets, turnips. In autumn it is celebrated on pomegranate and almonds.

In his studies, I.D. Mityaev [5] notes that Psammotettix dubovskyi Vilb. in Kazakhstan, a very numerous species in the foothills of the Zailiyskiy, Kirghizskiy and Talasskiy Alatau and in the Chulak mountains up to alpine meadows inclusive.

Our studies, in various zones of the Fergana Valley of Uzbekistan, have shown that this species is found on wheat, barley, oats, corn, rice and other crops.

In previous years, in 1995 and 1997, extensive damage to cereal crops was observed in the Fergana Valley due to the massive colonization of leafhoppers Psammotettix striatus (L.) [2].

Reliable diagnosis of these species and the study of their features are necessary for the development of scientifically based protective measures against them, in the event of favorable conditions for their reproduction and exceeding the economic threshold of harmfulness.

However, it must be remembered that these are beautiful, unusual species that give originality to the unique nature of the Fergana
Valley, which must be explored and be able to determine.

\section{CONCLUSION}

The study of cicadas is necessary, since many of them are pests of agricultural plants.

Some species carry dangerous viral plant diseases, and their identification is of great importance for the development of measures to combat them.

Species of cicadas of the genus Psammotettix Haupt living in Uzbekistan (Psammotettix striatus (L.) and Psammotettix dubovskyi Vilb.). Thanks to control, do not harm many farms, but, being potential pests of cereals and other crops, require the need to study, the ability to identify them and predict their reproduction.

\section{REFERENCES}

1. Kozhevnikova A.G. (2009) Cicadaceae (Auchenorrhyncha) damaging grain crops in farms of the Andijan region // Materials of the scientific conference "Actual problems of entomological science". Tashkent. - p. 79.

2. Kozhevnikova A.G. (2019) Cicadaceae (Auchenorrhyncha) are pests of agricultural crops in Uzbekistan. Monograph. - Publishing house "Fan va texnologiyalar". - Tashkent. - pp. 108-110.

3. Bey-Bienko G.Ya. (1980) General entomology. - Publishing house "Higher school". - Moscow. - pp. 108-110.

4. Dubovskiy G.K. (1966) Cicadaceae (Auchenorrhyncha) of the Fergana Valley. Fan. - Tashkent. - p. 215.

5. Mityaev I. D. (2001) Cicadids of Kazakhstan (Homoptera, Cicadinea). - The science. Alma-Ata. - p. 210.

6. Sulaimanov X.A. (1972) Cicadaceae of the Karshi steppe // pp. Ecology and biology of animals in Uzbekistan. - Tashkent. - p. 45.

7. Kozhevnikova A.G. (2019) Cicadaceous cereals of Uzbekistan and measures to 
The American Journal of Agriculture and Boimedical Engineering (ISSN - 2689-1018)

Published: October 31, 2020 | Pages: 87-91

Doi: https://doi.org/10.37547/tajabe/Volumeo2Issue10-15

2020: $5 \cdot 34$

OCLC - 1121105746

combat them. // Actual problems of modern science, no. 6 (109), ISSN 16802721. - Ed. "Sputnik +". - Moscow. - p. 180.

8. Emelyanov A.F. (1972) Suborder Auchenorrhyncha - cicadas // Sb. Insects and mites are pests of agricultural crops. Tashkent. - The science. - Leningrad: - p. 117. 